\title{
Applying multivariate analysis as decision tool for evaluating sediment-specific remediation strategies
}

Pedersen, Kristine B.; Lejon, Tore; Jensen, Pernille Erland; Ottosen, Lisbeth M.

Published in:

Chemosphere

Link to article, DOI:

10.1016/j.chemosphere.2016.02.063

Publication date:

2016

Document Version

Peer reviewed version

Link back to DTU Orbit

Citation (APA):

Pedersen, K. B., Lejon, T., Jensen, P. E., \& Ottosen, L. M. (2016). Applying multivariate analysis as decision tool for evaluating sediment-specific remediation strategies. Chemosphere, 151, 59-67.

https://doi.org/10.1016/j.chemosphere.2016.02.063

\section{General rights}

Copyright and moral rights for the publications made accessible in the public portal are retained by the authors and/or other copyright owners and it is a condition of accessing publications that users recognise and abide by the legal requirements associated with these rights.

- Users may download and print one copy of any publication from the public portal for the purpose of private study or research.

- You may not further distribute the material or use it for any profit-making activity or commercial gain

- You may freely distribute the URL identifying the publication in the public portal 


\section{Applying multivariate analysis as decision tool for evaluating \\ 2 sediment-specific remediation strategies}

3

$4 \quad$ Kristine B. Pedersen ${ }^{\mathrm{a}, \mathrm{c}}$, Tore Lejon ${ }^{* a}$ Pernille E. Jensen ${ }^{\mathrm{b}}$ and Lisbeth M. Ottosen ${ }^{\mathrm{b}}$

5 *Corresponding author: e-mail tore.lejon@uit.no; tel. +47 776 44736; fax. +47 77644765

6 a Department of Chemistry, University of Troms $\varnothing$, The Arctic University of Norway, Postbox

76050 Langnes, 9037 Troms $\varnothing$, Norway.

$8{ }^{b}$ Arctic Technology Centre, Department of Civil Engineering, Technical University of

9 Denmark, Building 118, 2800 Lyngby, Denmark

c Akvaplan-Niva AS, Framsenteret, Postbox 6606 Langnes, 9296 Troms $\varnothing$, Norway

Abstract

Multivariate methodology was employed for finding optimum remediation conditions for electrodialytic remediation of harbour sediment from an Arctic location in Norway. The parts of the experimental domain in which both sediment- and technology-specific remediation objectives were met were identified. Objectives targeted were removal of the sediment-specific pollutants $\mathrm{Cu}$ and $\mathrm{Pb}$, while minimising the effect on the sediment matrix by limiting the removal of naturally occurring metals while maintaining low energy consumption.

Two different cell designs for electrochemical remediation were tested and final concentrations of $\mathrm{Cu}$ and $\mathrm{Pb}$ were below background levels in large parts of the experimental domain when operating at low current densities $\left(<0.12 \mathrm{~mA} / \mathrm{cm}^{2}\right)$. However, energy consumption, remediation times and the effect on naturally occurring metals were different for the 2- and 3-compartment cells. 
Human activities have always affected the environment but with the industrial revolution, this has been accentuated and in contrast to early human activity, the problem reaches far beyond our local environment. Despite efforts to develop technology that will minimize pollution, there is still a need for treatment of already polluted water, soils, and sediments.

Sediments may contain complex mixtures of organic contaminants and/or heavy metals as pollution originates from different sources, e.g. shipping, shipyards, discharge of sewage, spills and from landbased activities. Depending on the nature of contamination and the location, it is sometimes possible to immobilize contaminants by capping. However, if sediments result from dredging, ex situ treatment will be necessary and to this end deep-sea dumping, aquatic containment and dumping at landfills have been employed. By treatment of sediments it is possible to minimize the amount of polluted material needing to be deposited (e.g. by removing courser, less contaminated fractions) or even to be able to reuse the sediments for other purposes (e.g. as construction material). The selection of the most appropriate technology for the remediation of sediments/soils thus depends on site-specific conditions, types of pollutants, pollutant concentrations and the end use of the treated sediment (Rulkens et al., 1998; Mulligan et al., 2001).

Organic pollutants are effectively destroyed by thermal remediation techniques but certain heavy metals ( $\mathrm{Hg}$, As and $\mathrm{Cd}$ ) may be volatilized in the process and others (Mo and $\mathrm{V}$ ) may become more leachable due to oxidation (Rulkens, 2005). Bioremediation (Guevara-Riba et al., 2004; Tabak et al., 2005) is one possible option, in which microorganisms are employed for immobilizing (White et al., 1997) or mobilizing (Erüst et al., 2013) metals that are part of natural biochemical cycles. Water soluble pollutants that are loosely bound to sediment particles may be solubilized before washing (Löser et al., 2007; Bing et al., 2008) and heavy metals have also been removed by extraction with strong acids (Dermont et al., 2008). Electrokinetic remediation offers another possibility that has been employed for both organic contaminants (Gomes et al., 2012; Méndez et al., 2012; Fan et al., 2016) and heavy metals (Gent et al., 2004; Kim et al., 2011; lannelli et al., 2015).

Applying electrodialysis, removal efficiencies of $>90 \%$ of heavy metals have been achieved for waste materials such as soil, sediments, fly ash, wood and sewage sludge (Ottosen et al., 1995; Ribeiro et al., 2000; Ferreira et al., 2002; Jakobsen et al., 2004; Nystroem et al., 2005a) while maintaining low energy consumption (Sun and Ottosen, 2012). Electrodialysis is based on the principles of electrokinetic remediation and relies on an electric field of low current being applied to the polluted material. Ion-exchange membranes are employed to control the transport of ions to and from the polluted material. In this way acidification of the contaminated material causing mobilization of metals bound in the sediment is ensured by either water splitting at the anion exchange membrane (Ottosen et al., 2000) or by direct introduction if protons produced at the anode.

The need for developing tools for selecting the most appropriate remediation technology and identifying the optimal site-specific remediation conditions is apparent. For this, different statistical tools may prove valuable and in a recent report the use of factorial design in optimizing the remediation of uranium polluted soils was reported (Radu et al., 2015). Another method is projections onto latent structures (PLS) which has been extensively used in chemical synthesis (Carlson and Carlson, 2005a) and also in studies of the influence of soil properties on PAH oxidation 
(Jonsson et al., 2007) and for identifying the most relevant variables for electrochemical treatment of sediments (Pedersen et al., 2015b; Pedersen et al., 2015c; Pedersen et al., 2015d).

PLS is a method suited for handling large data sets by calculating the quantitative relationship between independent variables and responses. By arranging the observations (e.g. experimental settings, sediment characteristics) in an X-matrix and the responses (e.g. removal of contaminants, energy consumption) in a Y-matrix, the correlation may be calculated and optimal experimental settings, within the experimental domain studied, may be identified. In contrast to regression methods, PLS is based on projections, making it a robust method that tolerates missing data.

The focus of this study was demonstrating the applicability of PLS to a sediment-specific remediation strategy for harbour sediment, exemplified by electrodialytic remediation. PLS was employed to determine optimal experimental settings in regard to the remediation objectives and was also used to evaluate energy consumption in the different parts of the experimental domain.

\section{Methods and materials}

\subsection{Sediment analyses}

The sediment from Hammerfest harbour $\left(40.17^{\circ} \mathrm{N}, 41.32^{\circ} \mathrm{E}\right)$, located in Norway, used in this study, has previously been found to contain levels of $\mathrm{Cu}$ and $\mathrm{Pb}$ above background levels according to the Norwegian sediment quality criteria (Pedersen et al., 2015a).

The sediment was from the top $10 \mathrm{~cm}$ of the seabed using a Van Veen grab in Hammerfest harbour, Norway. The samples were kept cool during transport and stored in a freezer $\left(-18^{\circ} \mathrm{C}\right)$ until analysed or treated.

Major elements and heavy metal concentrations ( $\mathrm{Al}, \mathrm{Fe}, \mathrm{K}, \mathrm{Mg}, \mathrm{Mn}, \mathrm{As}, \mathrm{Cr}, \mathrm{Cu}, \mathrm{Ni}, \mathrm{Pb}, \mathrm{Zn}$ ) were measured based on digestion (Norwegian standard NS4770). Sediment dried at $105^{\circ} \mathrm{C}(1.0 \mathrm{~g})$ and $\mathrm{HNO}_{3}(9 \mathrm{M}, 2 \mathrm{~mL})$ were autoclaved $\left(200 \mathrm{kPa}, 120^{\circ} \mathrm{C}, 30\right.$ minutes). Solid particles were subsequently removed by vacuum filtration through a $0.45 \mu \mathrm{m}$ filter and the liquid was diluted to $100 \mathrm{~mL}$. Metal concentrations in the liquid were measured by Inductively Coupled Plasma - Optical Emission Spectrometry (ICP-OES).

Carbonate content was measured by treating dried sediment $(5.0 \mathrm{~g})$ with $\mathrm{HCl}(3 \mathrm{M} ; 20 \mathrm{~mL})$ and the developed $\mathrm{CO}_{2}$ was measured volumetrically in a Scheibler apparatus, calibrated with $\mathrm{CaCO}_{3}$.

Organic content was based on loss of ignition on dried sediment $(2.5 \mathrm{~g})$ being heated at $550^{\circ} \mathrm{C}$ for an hour.

$p H(K C l)$. Dried sediment $(5.0 \mathrm{~g})$ was agitated with $\mathrm{KCl}(1 \mathrm{M}, 12.5 \mathrm{~mL})$ for an hour and $\mathrm{pH}$ was subsequently measured using a radiometric analytical electrode.

Grain size distribution was measured by wet sieving and dry sieving. Wet sediment $(75 \mathrm{~g})$, distilled water $(350 \mathrm{~mL})$ and $\mathrm{Na}_{4} \mathrm{P}_{2} \mathrm{O}_{7} .10 \mathrm{H}_{2} \mathrm{O}(0.1 \mathrm{M}, 10 \mathrm{~mL})$ was agitated for 24 hours. The slurry was then sieved through a $63 \mu \mathrm{m}$ sieve and the fraction above $63 \mu \mathrm{m}$ was subsequently dried and sieved for 15 minutes in a mechanical shaker using sieves with screen openings of $0.063,0.080,0.125,0.25,1.0$ and $2.0 \mathrm{~mm}$. The slurry fraction below $63 \mu \mathrm{m}$ was transferred to Andreasen pipette for gravitational 
sedimentation. Stoke's law was used for measuring time required for particles to settle $20 \mathrm{~cm}$ and samples representing the sizes $40,32,16,8,4,2$ and $1 \mu \mathrm{m}$ were sampled.

Sequential extraction was made in four steps based on the improvement of the three-step method (Rauret et al., 1999) described by Standards, Measurements and Testing Program of the European Union. Air-dried sediment $(0.5 \mathrm{~g})$ was first extracted with acetic acid $(0.11 \mathrm{M}, 20 \mathrm{~mL}, \mathrm{pH} 3)$ for 16 hours; secondly extracted with hydroxylammonium chloride $(0.1 \mathrm{M}, 20 \mathrm{~mL} ; \mathrm{pH} 2)$ for 16 hours; thirdly extracted with hydrogen peroxide $(8.8 \mathrm{M}, 5 \mathrm{~mL})$ for 1 hour, followed by extraction at $85^{\circ} \mathrm{C}$ for 1 hour, followed by evaporation of liquid at $85^{\circ} \mathrm{C}$, subsequently the cooled solid fraction was extracted with ammonium acetate $(1 \mathrm{M}, 25 \mathrm{~mL}, \mathrm{pH} 2)$ for $16 \mathrm{~h}$; and fourthly digestion on the remaining solid particles was made, following the description above.

\subsection{Electrodialytic remediation experiments}

\subsubsection{Materials and procedure}

Two different electrodialytic remediation (EDR) cells were employed in the study. The set-up and principles of the cell designs are illustrated in figure 1. The difference between the two is the insertion of an anode compartment in the extensively used 3-compartment cell. Acidification has been shown to occur faster in the 2-compartment cell and with a lower energy consumption. The faster mobilisation of metals may result in relatively higher release of naturally occurring metals into the liquid phase and for this reason the 3-compartment cell has in this study been used as a reference. Stirring has proven more efficient than a stationary set-up (Pedersen et al., 2003; Ottosen et al., 2012) and appears appropriate to apply for remediating dredged sediments. Other variables of importance to the efficiency of EDR include sediment, cell design, current density and time (Pedersen et al., 2015d; Pedersen et al., 2015e).

\section{Figure 1: EDR cell designs - the 3-compartment cell and the 2-compartment cell.}

The 2-compartment and 3-compartment cells used in the study were designed using the same materials and sizes; the 3-compartment cells consisted of two electrolyte compartment and between these a compartment containing the sediment suspension. The 2-compartment cell consisted of one electrolyte compartment (catholyte) and a compartment containing the sediment suspension. The cell compartments were manufactured from Plexiglas and the dimensions were: length of electrolyte compartments $3.5 \mathrm{~cm}$; length of sediment suspension compartment $10 \mathrm{~cm}$; inner diameter of all compartments $8 \mathrm{~cm}$. lon exchange membranes from lonics (anion exchange membrane 204 SZRA B02249C and cation exchange membrane CR67 HUY N12116B). The electrolyte was $\mathrm{NaNO}_{3}(0.01 \mathrm{M})$ adjusted to $\mathrm{pH} 2$ by $\mathrm{HNO}_{3}(5 \mathrm{M})$. The electrolyte liquids $(350 \mathrm{~mL}$ ) were circulated via Pan World pumps with flow rates of $30 \mathrm{~mL} / \mathrm{min}$. Platinum coated titanium electrodes were used in each electrolyte compartment and a power supply (Hewlett Packard E3612A) maintained a constant DC current. The sediment suspension was stirred by a RW11 Basic lab-egg (IKA 2830001) with a stirrer consisting of plastic flaps $(4 \mathrm{~cm} \times 0.5 \mathrm{~cm})$ fastened to a glass rod.

After the EDR experiments the sediment suspensions were filtered and the heavy metal concentration in both the suspension liquid and solids were measured. The stirrer, membranes and electrodes were rinsed in $\mathrm{HNO}_{3}(5 \mathrm{M})$ overnight and the heavy metal concentrations in the rinsing liquids as well as with the electrolyte liquids were measured by ICP-OES. 
The remediation objectives were related to achieving background concentrations of the two targeted heavy metals, $\mathrm{Cu}$ and $\mathrm{Pb}$ as well as limiting the removal of naturally occurring metals. The latter objective partly due to mobilised metals reducing the removal of targeted metals during electrokientic remediation (Kim et al., 2009) as well as ensuring that disposing of the suspension liquid after treatment does not create an environmental issue. Inorganic Al is for instance toxic to many aquatic species (Hindar and Lydersen, 1995; WHO, 1998; ATSDR, 2008; Pedersen et al., 2015e). Even though it has been shown that metals bound in both available and stable fractions of the sediment are removed during electrokinetic remediation (Kirkelund et al., 2010; Kim et al., 2011), the objective of limiting removal of metals was quantified to the amounts bound in the most available fraction (exchangeable). The means of determining amount of metal bound in the different fractions of the sediment was done by the BCR sequential extraction scheme in which the approximate distribution of metals in soils/sediments in the fractions exchangeable (including acid soluble), reducible, oxidisable and residual fractions (Rauret et al., 1999) is determined. Drawbacks of the method include potential readsorption and redistribution of metals during the sequential extraction; the method has, however, been found to be sufficiently repeatable and reproducible to be applied (Filgueiras et al., 2002).

\subsubsection{Experimental design}

The experimental variables varied in this study were current density and remediation time after acidification. A previous study revealed that excluding the acidification time (lag phase) improved model predictability (Pedersen et al., 2015d). Time after acidification in this study was calculated as time after the sediment suspension reached $\mathrm{pH} 4$.

For determining optimal experimental settings, two experimental designs for each cell were applied, based on fractional factorial designs of two variables resulting in two experiments in each design. These were supplemented with 1-2 experiments representing the centre point of the experimental domains. Due to the structure of the experimental designs, two of the experiments (no. 1 and 6 ) were included in two designs. Experiments 13-18 were conducted to test the predictability of the PLS models of the four experimental designs. The experimental settings are given in table 1.

Table 1: The experimental designs

\begin{tabular}{|l|l|l|l|l|}
\hline Experiment & Cell design & $\begin{array}{l}\text { Time after } \\
\text { acidification }\end{array}$ & $\begin{array}{l}\text { Current } \\
\text { density }\end{array}$ & $\begin{array}{l}\text { Exp. } \\
\text { design }\end{array}$ \\
\cline { 3 - 4 } & & (h) & $\left(\mathrm{mA} / \mathbf{c m}^{2}\right)$ & \\
\hline 1 & 3 -compartment & 48 & 0.04 & $1.1,1.2$ \\
\hline 2 & 3 -compartment & 246 & 0.28 & 1.1 \\
\hline 3 & 3 -compartment & 444 & 0.52 & 1.1 \\
\hline 4 & 3 -compartment & 278 & 0.20 & 1.2 \\
\hline 5 & 3 -compartment & 163 & 0.12 & 1.2 \\
\hline
\end{tabular}




\begin{tabular}{|c|c|c|c|c|}
\hline 6 & 2-compartment & 48 & 0.04 & $2.1,2.2$ \\
\hline 7 & 2-compartment & 246 & 0.28 & 2.1 \\
\hline 8 & 2-compartment & 444 & 0.52 & 2.1 \\
\hline 9 & 2-compartment & 48 & 0.20 & 2.2 \\
\hline 10 & 2-compartment & 163 & 0.12 & 2.2 \\
\hline 11 & 2-compartment & 163 & 0.12 & 2.2 \\
\hline 12 & 2-compartment & 278 & 0.04 & 2.2 \\
\hline 13 & 3-compartment & 246 & 0.36 & \\
\hline 14 & 3-compartment & 48 & 0.52 & \\
\hline 15 & 3-compartment & 444 & 0.20 & \\
\hline 16 & 2-compartment & 246 & 0.36 & \\
\hline 17 & 2-compartment & 48 & 0.52 & \\
\hline 18 & 2-compartment & 444 & 0.20 & \\
\hline
\end{tabular}

${ }^{1}$ Previously published in (Pedersen et al., 2015e)

1742 Previously published in (Pedersen et al., 2015c)

The power consumption in Wh (E) was calculated as:

$177 \int_{t=0}^{t} E=V I d t$

where $\mathrm{V}$ is the voltage between the electrodes $(\mathrm{V}), \mathrm{I}$ is the current $(\mathrm{A})$ and $\mathrm{t}$ is the remediation time (h).

\subsection{Multivariate modelling}

PLS was used for calculating the quantitative relation between a descriptor matrix (the experimental variables) and a response matrix (final metal concentrations; energy consumption).

\subsubsection{PLS modelling}

In this study SimcaP11 software was used for PLS modelling based on the 18 experiments in table 1. A quantitative relationship between a descriptor matrix containing the experimental variables (arranged by experiments in the rows and settings in the columns) and a response matrix (final concentrations of metals; energy consumption) was calculated. PLS models quantitative relations between a descriptor matrix, $X$, and a response matrix, $Y$ and can subsequently be used to calculate expected responses by entering new data into the $X$-matrix. If the number of independent variables in the $\mathrm{X}$-matrix is given by $K$ and the number of dependent variables in the $Y$-matrix is $M$, the objects (e.g. experiments) will be represented as points in the $K$-dimensional $X$ space (descriptors/variables) 
and the $M$-dimensional Y space (responses) (Wold et al., 2001; Carlson and Carlson, 2005b). Objects in each space are projected down to PLS components that describe the variation in each space with the constraint that for each PLS dimension, the PLS scores of the Y-matrix $(u)$ should have a maximum correlation to the scores of the X-matrix ( $t$ ) (Carlson and Carlson, 2005b; Eriksson et al., 2014). New PLS components are iteratively introduced until all the systematic variation in the $Y$ matrix has been exhausted and only noise remains. Advantages of PLS are that it provides plots of the data compressed to fewer dimensions than the original dataset, it can simultaneously model several responses and it copes with colinearity between variables, noise in both the $X$ and $Y$ matrices and moderate amounts of missing data (<20\%) (Wold et al., 2001; Trygg and Wold, 2002; Carlson and Carlson, 2005b). Moreover, since PLS is based on projections, it is possible to have more variables than objects (Carlson and Carlson, 2005b).

$\mathrm{R} 2 \mathrm{Y}$ is a measure of the fraction of the $\mathrm{Y}$ matrix explained by the model and the predictive power, Q2, is an estimate of the reliability of the model calculated by cross-validation. Sweet spot plots of the calculated PLS models were used as foundations for development of remediation strategies.

A sweet spot plot is essentially contour plots of all the responses as a function of two variables in one plot, and is based on the site-specific remediation objectives. The sweet spot plot thus highlights the areas of the experimental domain in which the different objectives are met. The number of objectives met are illustrated in different shades and the sweet spot is the part of the experimental domain in which all remediation objectives are met.

\section{Results and discussion}

\subsection{Sediment characteristics and EDR results}

Selected sediment characteristics are summarised in table 2, for more characteristics including conductivity and contents of chloride, carbon, phosphorous and sulphur, please refer to (Pedersen et al., 2015a). As is apparent in the table, the sediment used for experiments in this study has low contents of carbonate as well as organic matter, resulting in a low buffer capacity. Lower removal efficiencies of heavy metals from carbonaceous sediments during EDR treatment applying the same experimental settings have been reported (Nystroem et al., 2005a, b; Nystrom et al., 2005; Ottosen et al., 2007). The clay and silt fractions only constitute $25 \%$ of the sediment; none the less metal concentrations in each grain size fraction (clay, silt, sand, gravel) revealed that approximately 50$65 \%$ of the total metal content was found in these fractions $(<63 \mu \mathrm{m})$.

Table 2: Sediment characteristics, metal-binding patterns and metal removal during the EDR experiments. The concentrations of heavy metals of environmental concern are compared to the sediment quality criteria of the Norwegian Environment Agency as well as OSPAR (ratified by Norway) in table 2. OSPAR operates with two sets of criteria for background levels; background concentrations (BC) and background assessment concentrations (BAC). The latter are based on statistical calculations in which there is a $90 \%$ probability that the observed mean concentration will be below the BAC when the true mean concentration is equivalent to BC (OSPAR, 2009). The Norwegian sediment criteria for background levels (class 1 ) are based on similar calculations; the assessments of levels that pose low risks of adverse biological effects are based on national conditions (SFT, 2007). Cu and Pb exceed the BAC and Norwegian class 1 levels and are hence the targeted heavy metals in this study. The other 
analysed heavy metals $\mathrm{As}, \mathrm{Cd}, \mathrm{Cr}, \mathrm{Ni}$ and $\mathrm{Zn}$ have concentrations well below the sediment quality criteria and are equivalent to naturally occurring levels.

A previous study revealed a correlation between the concentrations of $\mathrm{Al}, \mathrm{Fe}, \mathrm{K}, \mathrm{Mg}, \mathrm{Mn}, \mathrm{Cr}$ and $\mathrm{Ni}$ bound in the residual fraction of the sediment indicating similar binding of these elements in the stable minerals of the sediment (Pedersen et al., 2015a). $\mathrm{Cu}, \mathrm{Pb}$ and $\mathrm{Zn}$ were found to have different binding patterns and this was in part attributed to anthropogenic sources rather than natural occurrence. This study supported this observation in that $\mathrm{Al}, \mathrm{Fe}, \mathrm{K}, \mathrm{Mg}, \mathrm{Mn}, \mathrm{Cr}$ and Ni were mainly bound in the residual and to a lesser degree the exchangeable fractions in the sediment (table 2), while $\mathrm{Cu}$ was mostly bound in the exchangeable and oxidisable fractions; $\mathrm{Pb}$ in the exchangeable fraction and $\mathrm{Zn}$ in the exchangeable and reducible fractions.

\subsection{Preliminary assessment of EDR experiments}

During EDR, removal from all fractions of the sediment has been reported in a previous study, initially relatively higher removal from the exchangeable, reducible and oxidisable fractions (Kirkelund et al., 2010). Comparing the removal of metals during EDR with the amounts bound in the different fractions of the sediment can hence provide foundation for assessing the approximate disturbance to the sediment, albeit not providing indications of possible accelerated weathering of the sediment during the EDR process.

For both cell designs the highest observed removal of metals exceeded the amounts bound in the available fractions (i.e. exchangeable, reducible and oxidisable) for $\mathrm{Al}, \mathrm{Fe}, \mathrm{Mg}, \mathrm{Mn}, \mathrm{Cr}$ and $\mathrm{Ni}$ indicating that regardless of design, EDR influences the stable minerals in the sediment. Higher removal of the naturally occurring metals were observed in the 2-compartment cell compared to the 3-compartment cell, possibly due to the lower final pH levels detected in the 2-compartment cell experiments. These observations are indications that the sediment matrix is affected to a larger degree in the 2-compartment than the 3-compartment cell. The 2-compartment cell was however more efficient regarding energy consumption (figure 1 ) while removal of the targeted heavy metals was similar for both cell types (table 2).

In the following multivariate analysis is applied to explore the experimental domain of both the 2compartment and 3-compartment cell designs and ultimately determine optimal settings for the studied sediment, depending on the most appropriate design in relation to the remediation objectives identified in the next section.

\subsection{Determining optimal experimental settings}

\subsubsection{Remediation objectives}

The remediation objectives in this study were to achieve final concentrations of the targeted metals, $\mathrm{Cu}$ and $\mathrm{Pb}$ equivalent to background concentrations as determined by the Norwegian sediment quality criteria (table 2), while maintaining removal of $\mathrm{Al}, \mathrm{Fe}, \mathrm{K}, \mathrm{Mg}, \mathrm{Mn}, \mathrm{Cr}$ and $\mathrm{Ni}$ below amounts bound in the exchangeable fractions (table 2). In addition, a low energy consumption objective was set so that the contribution of electricity for the EDR process to the total cost was low, $€ 20 / \mathrm{m}^{3} \mathrm{dry}$ sediment (see section 2.1 for details).

\subsubsection{Preliminary assessment of experimental domain}


A previous study showed that the EDR process in the two cell designs applied in this study differ from in each other with respect to acidification and metal mobilisation and should be modelled separately as they constitute entirely different experimental approaches. The first designs were based on obtaining overviews of the total studied experimental domain and the PLS models were calculated based on 3-4 experiments for each cell design (design 1.1 and 2.1 in table 1). Model 1.1 of the 3-compartment cell had a correlation factor, R2Y, of 0.72 and a predictive power, Q2, of 0.45 and model 2.1 of the 2-compartment cell had correlation factor R2Y of 0.88 and predictive power of 0.66 . The models for both designs were considered good and stable, and hence suitable for further evaluation of the experimental domain.

Remediation objectives for metal removal with regards to the targeted heavy metals ( $\mathrm{Cu}$ and $\mathrm{Pb})$ as well as the metals $\mathrm{Al}, \mathrm{Fe}, \mathrm{K}, \mathrm{Mg}, \mathrm{Mn}, \mathrm{Cr}$ and $\mathrm{Ni}$ (see section 2.3.2) were inserted into a sweet spot plot to evaluate in which parts of the experimental domain the remediation objectives in relation to the metal removal were met.
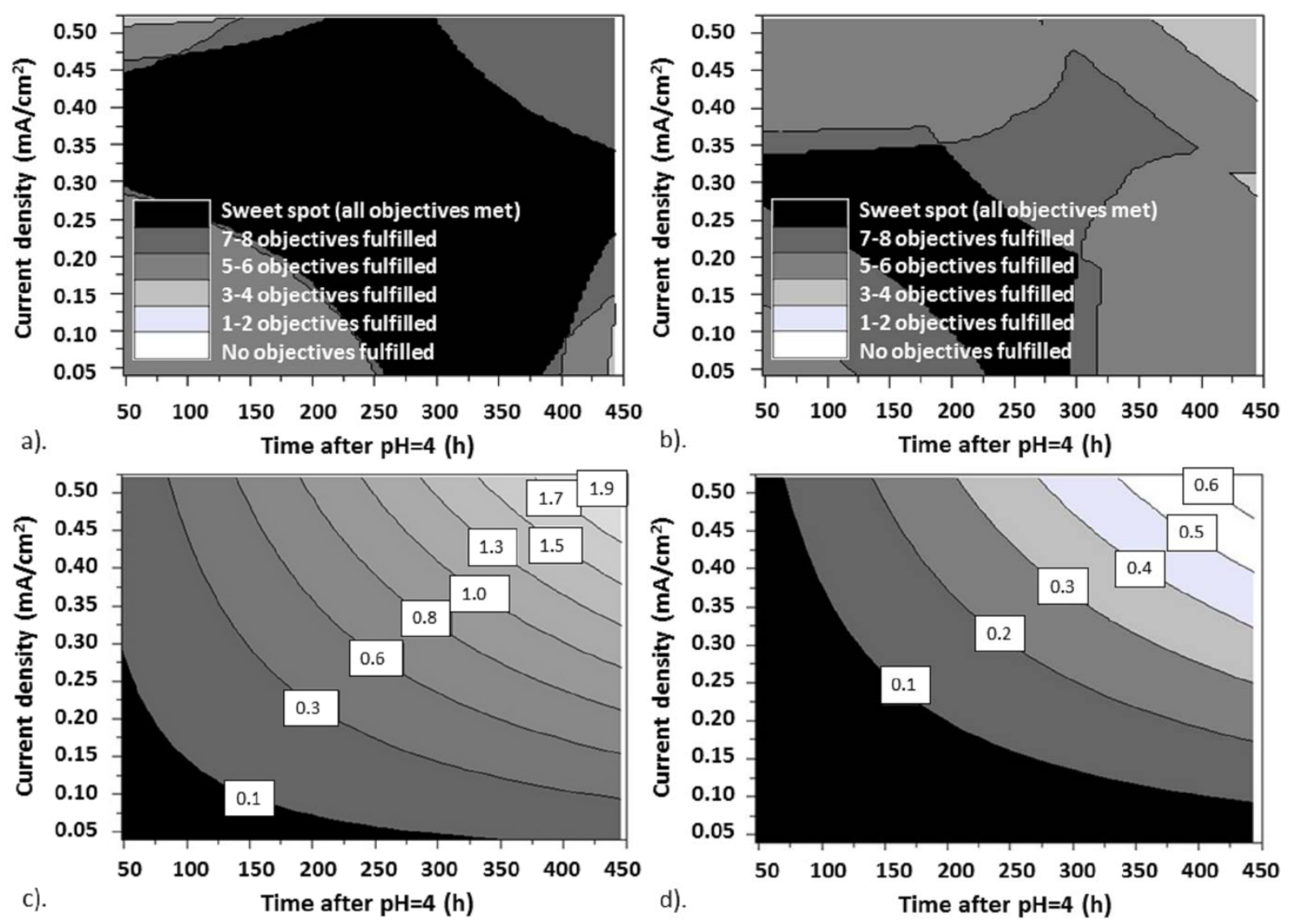

Figure 2: a) Sweet spot plot of the 3-compartment cell b). Sweet spot plot of the 2-compartment cell. For both cell designs, the remediation objectives were achieving final concentrations of $\mathrm{Cu}$ and $\mathrm{Pb}$ equivalent to background concentrations (Norwegian Class 1 ) and for $\mathrm{Al}, \mathrm{Fe}, \mathrm{Mg}, \mathrm{Mn}, \mathrm{Cr}$ and $\mathrm{Ni}$ less removal than the amounts bound in the exchangeable fractions of the untreated sediment. Figures $\mathrm{a}$ ) and b) illustrate the parts of the experimental domain in which all the remediation objectives were met (sweet spot). Contour plots of energy consumption ( $\mathrm{kWh} / \mathrm{kg} \mathrm{dry}$ sediment) for the $\mathrm{c}$ ). 3-compartment cell and d). the 2-compartment cell. The PLS models for c) and d) are based on design 1.1 (3-compartment cell) and 2.1 (2-compartment cell) with R2Y 0.800.84 and Q2 0.60-0.77. 
The sweet spots (dark shading) in figure 2, illustrate the experimental settings to operate within for meeting the specified remediation objectives for the removal of metals during EDR in both cell designs. The experimental domain to operate within in the 2-compartment cell (figure $2 \mathrm{~b}$ ) is significantly reduced compared to the 3-compartment cell (figure 2a) indicating a higher risk of removing metals from some of the more stable minerals in the sediment during EDR in the 2compartment cell design.

\subsubsection{Developing sediment specific remediation strategy}

Based on the sweet spot plots and energy consumption contour plots in figure 2, it was decided to further explore the part of the experimental domain of lower current densities and remediation times. Since the sweet spot plots revealed that remediation objectives might be achieved at current densities below $0.20 \mathrm{~mA} / \mathrm{cm}^{2}$ and time after acidification below 300h, the second designs were developed in the domain of $0.04-0.20 \mathrm{~mA} / \mathrm{cm}^{2}$ and $48-278 \mathrm{~h}$. The calculated PLS models 1.2 and 2.2 for the 3- and 2-compartment cells, respectively yielded correlation factors, R2Y, of 0.62-0.77 and predictive powers, Q2, of 0.40-0.67. The models were hence assessed as good, stable and suitable for evaluating this part of the experimental domain further.
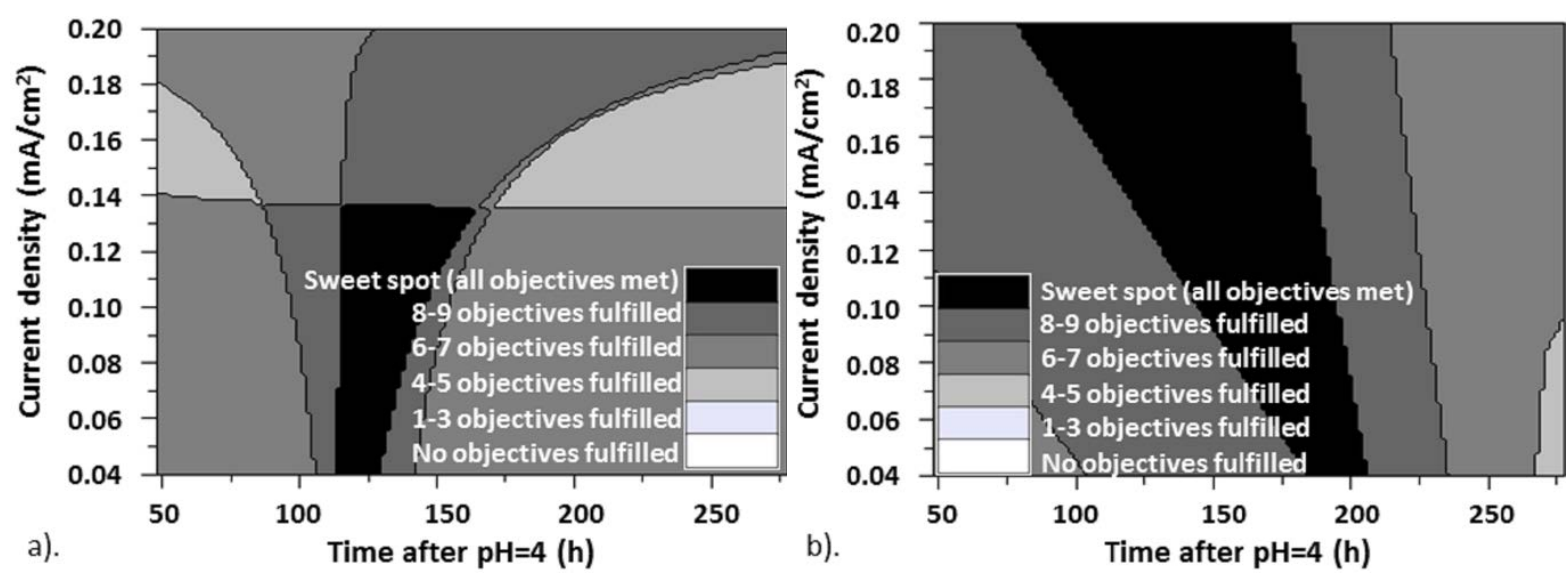

Figure 3: Sweet spot plots of a). model 1.2 (3-compartment cell) and b). model 2.2 (2-compartment cell) in the reduced experimental domain $48-278 \mathrm{~h} ; 0.04-0.20 \mathrm{~mA} / \mathrm{cm}^{2}$. Both models include remediation objectives for metal removal of $\mathrm{Al}, \mathrm{Fe}, \mathrm{Mg}, \mathrm{Mn}, \mathrm{Cr}, \mathrm{Ni}, \mathrm{Cu}$ and $\mathrm{Pb}$ as well as energy consumption (<0.1kWh/kg dry sediment).

In order to meet the remediation objectives in the 3-compartment cell, the difference in possible experimental settings is relatively small, but can be important in relation to the cost of electricity. Operating at $0.12 \mathrm{~mA} / \mathrm{cm}^{2}$ and 125 hours results in an energy consumption of $0.05 \mathrm{kWh} / \mathrm{kg}$ dry sediment giving an electricity cost per $\mathrm{m}^{3}$ dry sediment of 67NOK (€7.0) while operating at $0.04 \mathrm{~mA} / \mathrm{cm}^{2}$ and 110 hours results in a cost per $\mathrm{m}^{3}$ of $36 \mathrm{NOK}(€ 3.5)$. The latter settings provide the lowest cost of electricity in the shortest time within the experimental domain of the 3-compartment cell.

The difference in possible experimental settings for meeting the remediation objectives are larger in the 2-compartment cell and will depend on whether time or cost is more vital. Performing the experiments at $0.20 \mathrm{~mA} / \mathrm{cm}^{2}$ and $100 \mathrm{~h}$ (shortest possible time) results in an electricity cost of approximately $54 \mathrm{NOK} / \mathrm{m}^{3}(€ 5.5)$ while operating at $0.04 \mathrm{~mA} / \mathrm{cm}^{2}$ and $180 \mathrm{~h}$ would result in cubic 
meter price of $25 \mathrm{NOK} / \mathrm{m}^{3}(€ 3.0)$, the latter providing the lowest cost of electricity in the experimental domain of the 2-compartment cell. In comparison, dredging followed by disposal or treatment on land has a more than twenty-fold estimated cost in Norway.

\subsubsection{Model predictability}

330 In order to evaluate the predictability of the calculated PLS models, a comparison of model predicted

331 final concentrations and observed final concentrations of metals in experiments 13-18 (not

332 previously included in the PLS models). A previous study illustrated that PLS models that included several sediments might be applied for predicting starting points of remediation tests for new sediments (Pedersen et al., 2015c). In this study the PLS models only included one sediment and the predictions of final concentrations are more accurate. Figure 3 illustrates the trends of the metals $\mathrm{Al}$, $\mathrm{Cu}$ and $\mathrm{Pb}-\mathrm{Al}$ was chosen as a representative of the naturally occurring metals due to the potential toxic effects upon mobilisation.

338 The largest deviation between the model predictions and measured concentrations are found in 339 experiments 14 and 17 and is not surprising when considering that they were conducted in one of 340 the outer points of the experimental domain $\left(48 \mathrm{~h}\right.$ and $\left.0.52 \mathrm{~mA} / \mathrm{cm}^{2}\right)$ for each of the cell designs. At 341 this point, the predictions of $\mathrm{Al}$ and $\mathrm{Cu}$ are within a deviation of $25 \%$, which can be conceived as a 342 reasonable deviation when taking into account that the sediment is heterogeneous and that initial metal concentration analysis standard deviations were up to $32 \%$. The deviation between predicted and observed final concentrations of $\mathrm{Pb}$ is however not within this deviation and may be due to different binding patterns in the sediment resulting in larger deviations in the initial mobilisation occurring at $\mathrm{pH}$ levels 3-4 achieved in experiments 14 and 17. 

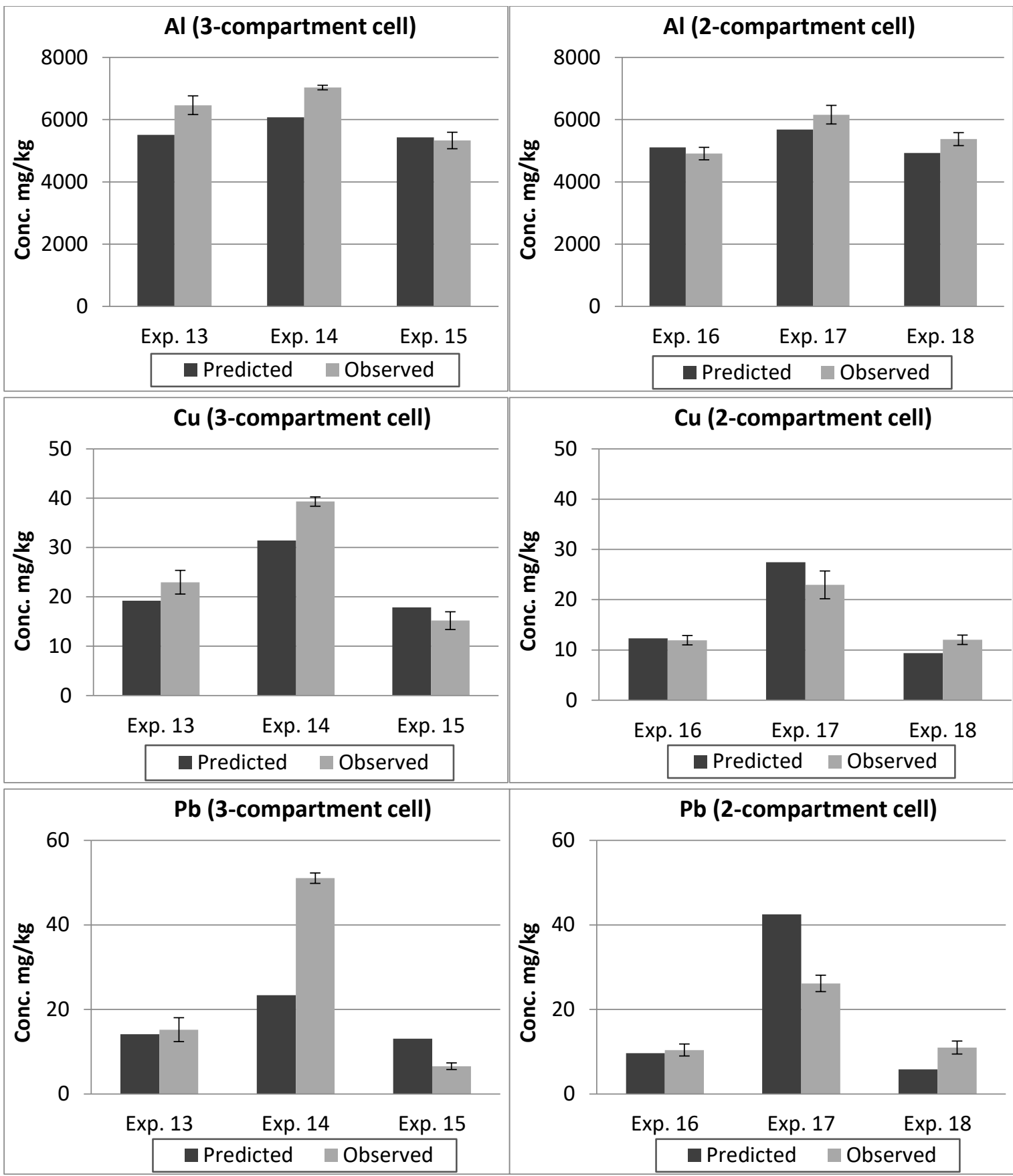

Figure 4: PLS models' (R2Y 0.6-0.7; Q2 0.5-0.6) predicted and observed concentrations of Al, Cu and $\mathrm{Pb}$ in experiments 13-15 for the 3-compartment cell and experiments 16-18 for the 2compartment cell. Standard deviations of the observed concentrations have been included in the figures.

The other experiments $13,15,16$ and 18 represent parts of the experimental domain closer to the model experiments and lower deviations between the predicted and registered final concentrations were observed. It is hence clear that model stability and predictability will improve with the number of experiments, as will any statistical method. However, the level of deviation in this study is reasonable for applying the models for determining remediation designs, when taking into account metal analysis standard deviations and the heterogeneous sediment. 
361 As evidenced from the above experiments, PLS proves a more efficient method for the rapid identification of remediation conditions than presented in other one-variable-at-a-time studies and with comparable or better results (Akcil et al., 2015). The results also provide a good foundation for later scaling up ((Pedersen et al., 2015e).

\section{Conclusions}

Multivariate analysis as a decision tool was effectively applied for evaluating remediation strategies for specific remediation technology (EDR) and sediment from the Arctic region of Norway in this study. The calculated PLS models were able to deal with sediment-specific clean-up level goals for the targeted pollutants as well as objectives specific to EDR, i.e. minimising removal of naturally occurring metals and maintaining a low energy consumption ( $<0.1 \mathrm{kWh} / \mathrm{kg}$ treated sediment) throughout the remediation.

The removal of the targeted heavy metals, $\mathrm{Cu}$ and $\mathrm{Pb}$ reached final concentrations equivalent to background levels as defined by the Norwegian authorities in large parts of the experimental domain for the two tested EDR cell designs. With the 2-compartment cell, higher removal rates of heavy metals and minimised use of energy was achieved in shorter time, while disturbance to the sediment matrix was lower in the 3-compartment cell. Optimising with regards to all parameters were however possible in both cell designs for the specific sediment. In the 3-compartment cell the lowest approximate electricity cost for meeting the remediation objectives was estimated to be $36 \mathrm{NOK} / \mathrm{m}^{3}$ dry sediment (€3.5), while being approximately $25 \mathrm{NOK} / \mathrm{m}^{3}$ dry sediment $(€ 3.0)$ in the 2compartment cell.

An evaluation of the model predictability showed good correspondence between model predicted and observed final metal concentrations. Based on the results in this study, the use of multivariate analysis is encouraged for other remediation studies, independent of method of choice.

\section{Acknowledgements}

The Northern Environmental Waste Management (EWMA) project, funded by the Research Council of Norway through NORDSATSNING (grant number 195160) and Eni Norge AS, is acknowledged for funding. Hammerfest municipality is acknowledged for providing boat and assistance in sampling of sediments.

\section{References}

Akcil, A., Erust, C., Ozdemiroglu, S., Fonti, V., Beolchini, F., 2015. A review of approaches and techniques used in aquatic contaminated sediments: metal removal and stabilization by chemical and biotechnological processes. Journal of Cleaner Production 86, 24-36.

ATSDR, 2008. Toxicological Profile for Aluminum. Agency for toxic substances and disease registry (ATSDR), US Deparment of Health and Human Services, Atlanta, pp. 175-227. Bing, P., GAO, H.-m., CHAl, L.-y., SHU, Y.-d., 2008. Leaching and recycling of zinc from liquid waste sediments. Transactions of Nonferrous Metals Society of China 18, 1269-1274. 
Carlson, R., Carlson, J.E., 2005a. Chapter 1 Introduction: Strategies on different levels in organic synthesis. in: Rolf, C., Johan, E.C. (Eds.). Data Handling in Science and Technology. Elsevier, pp. 1-13. Carlson, R., Carlson, J.E., 2005b. Chapter 18 Quantitative relations: Observed responses and experimental variations. in: Rolf, C., Johan, E.C. (Eds.). Data Handling in Science and Technology. Elsevier, pp. 425-469.

Dermont, G., Bergeron, M., Mercier, G., Richer-Lafleche, M., 2008. Soil washing for metal removal: a review of physical/chemical technologies and field applications. Journal of Hazardous Materials 152, $1-31$.

Eriksson, L., Trygg, J., Wold, S., 2014. A chemometrics toolbox based on projections and latent variables. Journal of Chemometrics 28, 332-346.

Erüst, C., Akcil, A., Gahan, C.S., Tuncuk, A., Deveci, H., 2013. Biohydrometallurgy of secondary metal resources: a potential alternative approach for metal recovery. Journal of Chemical Technology and Biotechnology 88, 2115-2132.

Fan, G., Cang, L., Gomes, H.I., Zhou, D., 2016. Electrokinetic delivery of persulfate to remediate PCBs polluted soils: Effect of different activation methods. Chemosphere 144, 138-147.

Ferreira, C., Ribeiro, A.B., Ottosen, L.M., 2002. Study of different assisting agents for the removal of heavy metals from MSW fly ashes. Waste Management and the Environment, 171-179.

Filgueiras, A.V., Lavilla, I., Bendicho, C., 2002. Chemical sequential extraction for metal partitioning in environmental solid samples. J Environ Monitor 4, 823-857.

Gent, D.B., Bricka, R.M., Alshawabkeh, A.N., Larson, S.L., Fabian, G., Granade, S., 2004. Bench-and field-scale evaluation of chromium and cadmium extraction by electrokinetics. Journal of Hazardous Materials 110, 53-62.

Gomes, H.I., Dias-Ferreira, C., Ribeiro, A.B., 2012. Electrokinetic remediation of organochlorines in soil: enhancement techniques and integration with other remediation technologies. Chemosphere 87, 1077-1090.

Guevara-Riba, A., Sahuquillo, A., Rubio, R., Rauret, G., 2004. Assessment of metal mobility in dredged harbour sediments from Barcelona, Spain. Science of the Total Environment 321, 241-255. Hindar, A., Lydersen, E., 1995. Er utfelt/sedimentert aluminium etter vassdragskalking et mulig miljøproblem? (Norwegian). NIVA, Oslo, Norway.

lannelli, R., Masi, M., Ceccarini, A., Ostuni, M., Lageman, R., Muntoni, A., Spiga, D., Polettini, A., Marini, A., Pomi, R., 2015. Electrokinetic remediation of metal-polluted marine sediments: experimental investigation for plant design. Electrochimica Acta 181, 146-159. Jakobsen, M.R., Fritt-Rasmussen, J., Nielsen, S., Ottosen, L.M., 2004. Electrodialytic removal of cadmium from wastewater sludge. J Hazard Mater 106, 127-132.

Jonsson, S., Persson, Y., Frankki, S., van Bavel, B., Lundstedt, S., Haglund, P., Tysklind, M., 2007. Degradation of polycyclic aromatic hydrocarbons (PAHs) in contaminated soils by Fenton's reagent: A multivariate evaluation of the importance of soil characteristics and PAH properties. Journal of Hazardous Materials 149, 86-96.

Kim, K.-J., Kim, D.-H., Yoo, J.-C., Baek, K., 2011. Electrokinetic extraction of heavy metals from dredged marine sediment. Separation and purification technology 79, 164-169.

Kim, K.-W., Lee, K.-Y., Kim, S.-O., 2009. Electrokinetic Remediation of Mixed Metal Contaminants. Electrochemical Remediation Technologies for Polluted Soils, Sediments and Groundwater. John Wiley \& Sons, Inc., pp. 285-313.

Kirkelund, G.M., Ottosen, L.M., Villumsen, A., 2010. Investigations of $\mathrm{Cu}, \mathrm{Pb}$ and $\mathrm{Zn}$ partitioning by sequential extraction in harbour sediments after electrodialytic remediation. Chemosphere 79, 9971002.

Löser, C., Zehnsdorf, A., Hoffmann, P., Seidel, H., 2007. Remediation of heavy metal polluted sediment by suspension and solid-bed leaching: estimate of metal removal efficiency. Chemosphere $66,1699-1705$. 
Méndez, E., Pérez, M., Romero, O., Beltrán, E., Castro, S., Corona, J., Corona, A., Cuevas, M., Bustos, E., 2012. Effects of electrode material on the efficiency of hydrocarbon removal by an electrokinetic remediation process. Electrochimica Acta 86, 148-156. Mulligan, C.N., Yong, R.N., Gibbs, B.F., 2001. Remediation technologies for metal-contaminated soils and groundwater: an evaluation. Engineering Geology 60, 193-207. of heavy metals induced by water splitting in electrodialytic remediation. Separ Sci Technol 40, 2245 2264.

Nystroem, G.M., Ottosen, L.M., Villumsen, A., 2005b. Electrodialytic removal of $\mathrm{Cu}, \mathrm{Zn}, \mathrm{Pb}$, and $\mathrm{Cd}$ from harbor sediment: Influence of changing experimental conditions. Environ Sci Technol 39, 29062911.

Nystrom, G.M., Ottosen, L.M., Villumsen, A., 2005. Test of experimental set-ups for electrodialytic removal of $\mathrm{Cu}, \mathrm{Zn}, \mathrm{Pb}$ and $\mathrm{Cd}$ from different contaminated harbour sediments. Eng Geol 77, 349-357. OSPAR, 2009. CEMP assessment report: 2008/2009 Assessment of trends and concentrations of selected hazardous substances in sediments and biota. OSPAR, www.ospar.org.

Ottosen, L., Jensen, J.B., Villumsen, A., Laursen, S., Hansen, H.K., Sloth, P., 1995. Electrokinetic remediation of soil polluted with heavy metals - Experiences with different kinds of soils and different mixtures of metals. Contaminated Soil '95, Vols 1 and 2 5, 1029-1038.

Ottosen, L.M., Hansen, H.K., Hansen, C.B., 2000. Water splitting at ion-exchange membranes and potential differences in soil during electrodialytic soil remediation. Journal of Applied Electrochemistry 30, 1199-1207.

Ottosen, L.M., Jensen, P.E., Kirkelund, G.M., Ferreira, C.D., Hansen, H.K., 2012. Electrodialytic Remediation of Heavy Metal Polluted Soil - treatment of water saturated or suspended soil. Chemical Engineering Transactions 28, 103-108.

Ottosen, L.M., Nystrom, G.M., Jensen, P.E., Villumsen, A., 2007. Electrodialytic extraction of Cd and Cu from sediment from Sisimiut Harbour, Greenland. J Hazard Mater 140, 271-279.

Pedersen, A.J., Ottosen, L.M., Villumsen, A., 2003. Electrodialytic removal of heavy metals from different fly ashes - Influence of heavy metal speciation in the ashes. J Hazard Mater 100, 65-78. Pedersen, K., Lejon, T., Jensen, P., Ottosen, L., 2015a. Chemometric Analysis for Pollution Source Assessment of Harbour Sediments in Arctic Locations. Water Air Soil Pollut 226, 1-15.

Pedersen, K.B., Jensen, P.E., Ottosen, L.M., Lejon, T., 2015b. An optimised method for electrodialytic removal of heavy metals from harbour sediments. Electrochimica Acta 173, 432-439.

Pedersen, K.B., Kirkelund, G.M., Ottosen, L.M., Jensen, P.E., Lejon, T., 2015c. Multivariate methods for evaluating the efficiency of electrodialytic removal of heavy metals from polluted harbour sediments. Journal of Hazardous Materials 283, 712-720.

Pedersen, K.B., Lejon, T., Ottosen, L.M., Jensen, P.E., 2015d. Screening of variable importance for optimizing electrodialytic remediation of heavy metals from polluted harbour sediments.

Environmental Technology 36, 2364-2373.

Pedersen, K.B., Ottosen, L.M., Jensen, P.E., Lejon, T., 2015e. Comparison of 2-compartment, 3compartment and stack designs for electrodialytic removal of heavy metals from harbour sediments. Electrochimica Acta 181, 48-57.

Radu, A., Panturu, E., Woinaroschy, A., Isopescu, R., 2015. Experimental Design and Process Optimization for Uranium Polluted Soils Decontamination by Acid Washing. Water Air Soil Pollut 226, 1-11.

Rauret, G., Lopez-Sanchez, J.F., Sahuquillo, A., Rubio, R., Davidson, C., Quevauviller, P., 1999. Improvement of the BCR three step sequential extraction procedure prior to the certification of new sediment and soil reference materials. J Environ Monitor 1, 57-61.

Ribeiro, A.B., Mateus, E.P., Ottosen, L.M., Bech-Nielsen, G., 2000. Electrodialytic removal of $\mathrm{Cu}, \mathrm{Cr}$, and As from chromated copper arsenate-treated timber waste. Environ Sci Technol 34, 784-788. Rulkens, W., 2005. Introduction to the treatment of polluted sediments. Reviews in Environmental Science and Bio/Technology 4, 213-221. 
498 Rulkens, W.H., Tichy, R., Grotenhuis, J.T.C., 1998. Remediation of polluted soil and sediment:

499 perspectives and failures. Water Science and Technology 37, 27-35.

500 SFT, 2007. Guidelines for classification of environmental quality in fjords and coastal waters

501 (Norwegian). in: Agency), S.n.N.E. (Ed.). SFT.

502 Sun, T.R., Ottosen, L.M., 2012. Effects of pulse current on energy consumption and removal of heavy

503 metals during electrodialytic soil remediation. Electrochim Acta 86, 28-35.

504 Tabak, H.H., Lens, P., van Hullebusch, E.D., Dejonghe, W., 2005. Developments in bioremediation of

505 soils and sediments polluted with metals and radionuclides-1. Microbial processes and mechanisms

506 affecting bioremediation of metal contamination and influencing metal toxicity and transport.

507 Reviews in Environmental Science and Bio/Technology 4, 115-156.

508 Trygg, J., Wold, S., 2002. Orthogonal projections to latent structures (O-PLS). Journal of

509 Chemometrics 16, 119-128.

510 White, C., Sayer, J., Gadd, G., 1997. Microbial solubilization and immobilization of toxic metals: key

511 biogeochemical processes for treatment of contamination. FEMS microbiology reviews 20, 503-516.

512 WHO, 1998. Aluminium in drinking water - Background document for development of WHO

513 Guidelines for Drinking-water Quality. Health criteria and other supporting information, Geneva.

514 Wold, S., Sjöström, M., Eriksson, L., 2001. PLS-regression: a basic tool of chemometrics.

515 Chemometrics and Intelligent Laboratory Systems 58, 109-130. 